\title{
Racial Orders, Congress, and the Agricultural Welfare State, $1865-1940$
}

\section{Kimberley S. Johnson, Barnard College, Columbia University}

\begin{abstract}
One of the key questions posed by analysts of modern, twentieth-century agricultural politics is, "How and when did agrarian democracy end and the dominance of agribusiness interests begin?" In this article I argue that the roots of this transformation lie in the origins of the agricultural welfare state and the overlapping of its birth with distinct eras in America's racial orders — those moments in time when political players mobilized coalitions and institutions around racial issues such as slavery, Reconstruction, or the segregated state of the Jim Crow order. As a result of these historical overlaps, the agricultural welfare state was shaped in surprising and not-wellunderstood ways by America's racial orders. In order to trace these two intertwining aspects of racial governance and agricultural welfare state development, I provide a reinterpretation of the development of the agricultural welfare state from its Civil War origins to its New Deal transformation. I show that, from 1865 to 1964, the confluence of racial orders, partisan alignments, and congressional orders created an agricultural welfare state in which African Americans were variously included and excluded in a pattern of "two-tier" citizenship. The broader racial governance aims of the Jim Crow order also had a significant role in shaping the development of the organizational ethos and administrative structures and practices within the United States Department of Agriculture (USDA). The practice of "two-tier" agricultural citizenship, which initially affected only African American and other minority farmers, was gradually extended to reflect the divide between large commercial farmers and the rural poor (including small farmers). The results from this analysis strengthen our understanding of how the American welfare state has been shaped - in particular, the ways in which racial governance and racial orders are deeply embedded in the American state building process.
\end{abstract}

\section{INTRODUCTION}

The United States Department of Agriculture (USDA) formally ended segregation among its staff, and in the agency's administration of federal farm policies in the wake of the 1964 Civil Rights Act. ${ }^{1}$ The agency was to return to its roots in "helping people [farmers] overcome the obstacles that stand

For their helpful comments on past versions of this paper, the author thanks Desmond King, Adrienne Petty, Elizabeth Sanders, Mary Summers, the editors of Studies in American Political Development, and two anonymous reviewers. An earlier draft of this essay was presented at the 2009 Congress \& History Conference at the University of Virginia.

1. Orville V. Freeman, "Memorandum: Federal Participation in Segregated Meetings," June 23, 1964, in Equal Opportunity in Farm Programs: An Appraisal of Services Rendered by Agencies of the United States Department of Agriculture, United States Commission on Civil Rights (Washington, DC: GPO, 1965). The USDA was also bound by previous nondiscrimination executive orders issued in 1948 (E.O. 9980), 1955 (E.O. 10590), 1961 (E.O. 10925), 1963 (E.O. 11114). in the way of their progress." ${ }^{2}$ In response to Pigford v. Glickman, a class action lawsuit brought by African American farmers, in 1999 the USDA agreed to a billion-dollar settlement. These farmers alleged that since the 1960s, the USDA had engaged in a longstanding pattern of discrimination in the granting of loans and subsidies to black farmers. The plaintiffs argued that one of the effects of this discriminatory policy was a crisis in black agriculture. The number of black farmers had dropped from 184,000 in 1964 to less than 19,000 in $1997 .{ }^{3}$ How discriminatory action continued within a federal agency decades

2. See Equal Opportunity in Farm Programs, 20.

3. For discussion of lawsuits brought against the USDA see Timothy Pigford, et al., v. Dan Glickman, Secretary, United States Department of Agriculture, US District Court for the District of Columbia, Civil Action No. 97-1978 (PLF), Paul L. Friedman, U.S. District Judge. See also Jerry Hagstrom, "The Last Plantation," Government Executive.Com (May 1, 1997). For figures on black farmers, see Bruce J. Reynolds, Black Farmers in America, 1865-2000: The Pursuit of Independent Farming and the Role of Cooperatives. (Washington, DC: US Department of Agriculture, 2002). 
after such behavior had been prohibited is an interesting question as it reflects a long-standing debate within the study of racial politics: Is racial discrimination in governing the result of individual acts, or is it the result of institutional/organizational patterns and structures?

This debate has particular resonance for those interested in the study of American political development, as it reflects in many ways an underlying tension within the field about questions of agency versus structure. ${ }^{4}$ When looking at the intersection of race and political development, the question becomes even more acute: When does race matter; and how does race matter when thinking about the shaping of the American state?

That is, how and when are racial identities used to shape political, civil, and social rights as well as governing arrangements? Are such decisions the result of individual actors, the result of institutional structure, or some combination of the two? More pointedly, was racial governance the epiphenomena of the state building process, or was racial governance a constitutive part of the state building process? ${ }^{5}$

The USDA, and in particular its origins, is a good place to begin to ask these kinds of questions, as the agency stands at the heart of America's first welfare state. The agricultural welfare state was created in the mid-nineteenth century by agrarian activist groups in order to aid small farmers in coping with and adapting to the stresses caused by emerging modern capitalism. The agricultural welfare state rested on the belief that it was the responsibility of the federal government to protect the well-being of individuals involved directly in the agricultural sector as producers, or who, by virtue of residency in a rural area, were considered part of the agricultural sector. Initially the benefits and services of the agricultural welfare state were available to all who met this expansive definition of agricultural citizenship. The ultimate goal of the agricultural welfare state was to strengthen the political, economic, and moral fiber of rural America, repository of the nation's values. ${ }^{6}$

4. See essays in Classifying by Race, ed. Paul E. Peterson (Princeton: Princeton University Press, 1995), as well as discussion of agency/structure issues throughout Karen Orren and Stephen Skowronek's The Search for American Political Development (New York: Cambridge University Press, 2004).

5. On the first question, see Michael Omi and Harold Winant, Racial Formation in the United States: From the 1960s to the 1990s (New York: Routledge Press, 1994). On the second question, see Joseph Lowndes, Julie Novkov, and Dorian T. Warren, eds., Race and American Political Development (New York: Routledge Press, 2007).

6. For discussion of the agricultural welfare state see Grant McConnell, Decline of Agrarian Democracy (New York: Atheneum, 1969), 3-18; Roy V. Scott, Reluctant Farmer: The Rise of Agricultural Extension to 1913 (Urbana: University of Illinois Press, 1970), 3763; Elizabeth Sanders, Roots of Reform: Farmers, Workers, and the American State, 1877-1917 (Chicago: University of Chicago Press, 1999);
The emergence of the agricultural welfare state overlapped with distinct eras in America's racial orders: those moments in time when political actors mobilized coalitions and institutions around racial issues such as slavery, Reconstruction, or the segregated state of the Jim Crow order. ${ }^{7}$ I suggest in this article that rather than this being a historical coincidence, the development of the agricultural welfare state was shaped in surprising and not-wellunderstood ways by America's racial orders. In order to trace these two intertwining aspects of racial governance and agricultural welfare state development, I here provide a reinterpretation of the development of the agricultural welfare state from its Civil War origins to its New Deal transformation.

From 1865 to 1964, the confluence of racial orders, partisan alignments, and congressional orders created an agricultural welfare state in which African Americans were variously included and excluded in a pattern of two-tier citizenship. Though the Jim Crow order was primarily directed at black farmers, its broader racial governance aims also had a significant, though less-well-understood, role in shaping the development of the organizational ethos and administrative structures and practices within the USDA. The practice of "two-tier" agricultural citizenship, which initially only affected African American and other minority farmers, was gradually extended to reflect the divide between large commercial farmers and the rural poor (including small farmers).

The existence of this pattern of differential citizenship is helpful in answering one of the key questions posed by analysts of modern, twentieth-century agricultural politics: How and when did agrarian democracy end and the dominance of agribusiness interests begin? Political scientists from Grant McConnell to Adam Sheingate point to the emergence of the American Farm Bureau Federation and other agricultural interest groups during the 1920 s as the key moment in which agricultural policy began to reflect the interests of narrow producer groups rather than farmers as

Elisabeth Clemens, The People's Lobby: Organization Innovation and the Rise of Interest Group Politics in America, 1890-1925 (Chicago: University of Chicago Press, 1997), 145-83; and Mary Summers, "Putting Politics Back In: Rethinking Agricultural Policies and Politics," Agricultural History 70 (1996): 395-414. Adam Sheingate defines the agricultural welfare state as the "production controls and price supports [which operate] to protect farmer's incomes" (Rise of the Agricultural Welfare State, Princeton: Princeton University Press, 2001), 3; and also John Mark Hansen, Gaining Access: Congress and the Farm Lobby, 1919-1981 (Chicago: University of Chicago Press, 1991). See Daniel Carpenter's The Forging of Bureaucratic Autonomy (Princeton: Princeton University Press, 2001), which offers a more statecentered account of agricultural welfare state development.

7. For discussion of racial orders, see Desmond King and Rogers Smith, "Racial Orders in American Political Development," American Political Science Review 99 (2005): 75-92. 
a whole. ${ }^{8}$ I suggest here that racial governance is an important factor for understanding the decline of agrarian democracy and the rise of private interests.

First, by introducing racial ordering into accounts of agricultural welfare state development, renewed attention can be paid to the services-based agricultural welfare state and the role that race played in shaping this moment in agricultural welfare state development. Early disputes over local control of services-based agricultural policy, primarily reflecting the interests of the Jim Crow southern racial order, resulted in the creation of differential citizenship status within the agricultural welfare state. Differential citizenship was accompanied by the development within the USDA of administrative structures in which a significant degree of discretionary power over the implementation of agricultural policy was vested at the subnational level, with states and increasingly with local institutions. Thus, as the policy tools of the agricultural welfare state shifted from the provision of services to a subsidy-based welfare state during the 1920s, economically advantaged local interests were able to control these administrative entities and the subsidy tools for their own benefit. Less economically powerful farmers, particularly farmers without prospects for landownership, were increasingly marginalized from the agricultural welfare state. As a result, by the time of the New Deal, an administrative structure created to partially govern on the basis of race became an important tool by which to govern on the basis of class and landtenure status.

While African American farmers were harmed by this new pattern of exclusion, many more non-African American farmers were harmed as well. In the end, what was fatally weakened was the notion of a broadly inclusive agricultural welfare state based on democratic and egalitarian agrarian citizenship. In its stead arose a two-tier system of welfare state provision. ${ }^{9}$ The takeover of the USDA's local administrative structures meant that the "haves" of agriculture were afforded income protection on an as-of-right basis, while the "have-nots" were relegated to rural welfare programs. ${ }^{10}$ Whereas before the New Deal differential citizenship only existed for African Americans and other racial/ethnic minorities, by the end of the New Deal differential citizenship was established across the entire agricultural welfare state. By

8. See Sheingate, The Rise of the Agricultural Welfare State, McConnell, Decline of Agrarian Democracy; Hansen, Gaining Access.

9. On the two-tier social welfare system, see not only Robert Lieberman's Shifting the Color Line (Cambridge, MA: Harvard University Press, 1998) but also Suzanne Mettler, Dividing Citizens: Gender and Federalism in New Deal Public Policy (Ithaca, NY: Cornell University Press, 1998).

10. For discussion of "haves" and "have-nots," see V.O. Key, Southern Politics in State and Nation (New York: Alfred A. Knopf, 1949), 298-310. the time the USDA reasserted stronger federal control over the system by the mid-1950s, the two-tier agricultural welfare state had been firmly established, and indeed exists to this day.

\section{Multiple Orders and Political Development}

Recent scholarship, in particular the work of Orren and Skowronek, has conceptualized American political development as more than just the centralization of power and growth of state capacity in national institutions; instead political development is conceived of as a process of "intercurrence," in which the United States can be understood as a "polity constructed through multiple, asymmetric orderings of authority." 11 The orderings of authority or political orders are defined as a "constellation of rules, institutions, practices, and ideas that hang together over time, a bundle of patterns ... exhibiting coherence and predictability while other things change around them." 12 Three different types of political orderings shaped the development of the agricultural welfare state: racial ordering, partisan ordering, and congressional orders. Focusing on the development of the agricultural welfare state is important for understanding the broader paths of American state development. $^{13}$ As Elizabeth Sanders and Elisabeth Clemens show, agrarian discontent and subsequent political mobilization were the key elements in the adoption of political and institutional developments that set the stage for the emergence of the modern American state. ${ }^{94}$ As a result of this agrarian activism, as Skocpol and Feingold (1982) note, the USDA, and the welfare state in which it played a key role, emerged as an "island of state strength" in an otherwise weak national state; it was the site where farmers and other interests were eventually "state-broken," i.e., trained to look to the USDA as the key actor in solving the problems of agriculture. ${ }^{15}$ The agricultural welfare state not only became the structure onto which other, newer parts of the American state, such as federal aid to state highways, were grafted, but the programs under its aegis also became the inspiration for other kinds of welfare state development such as the Sheppard-Towner maternal health program. Because of the importance of these linkages and later developments, understanding the development of the

11. Orren and Skowronek, Search for American Political Development, 182.

12. Ibid., 14-15.

13. For a classic discussion of the "American state" in this era, see Stephen Skowronek, Building a New American State: The Expansion of National Administrative Capacities, 1877-1920 (New York: Cambridge University Press, 1982).

14. See Sanders, Roots of Reform as well as Clemens, The People's Lobby.

15. See Theda Skocpol and Martin Feingold, "State Capacity and Economic Intervention in the Early New Deal," Political Science Quarterly 97 (1982): 271, 274 
agricultural welfare state has long been of interest in the study of American political development. ${ }^{16}$

An overlooked aspect of this earlier research on the agricultural welfare state has been the role of race, and particularly the role of the Jim Crow order, in shaping its development. The Jim Crow order was a geographically and temporally specific set of racial governance arrangements centered in and largely restricted to the South that arose after the end of the first Reconstruction and ended with the Second Reconstruction initiated by the modern civil rights movement. ${ }^{17}$ The Jim Crow order was a racial political order in which "political actors ... adopted (and often adapted) racial concepts, commitments, and aims in order to bind together their coalitions and structure governing institutions that express and serve their architects." 18

The legitimacy and authority of the Jim Crow order rested upon and was inextricably linked to the political subordination and economic impoverishment of white as well as black farmers. By 1908, the Jim Crow order had been firmly established with the near total disenfranchisement of African Americans, and a substantial decline in political participation amongst whites. ${ }^{19}$ The agrarian economy of the South reflected this racial inequality as well as the racial distinctiveness of the Jim Crow order. In 1910, approximately 90 percent of African Americans lived in the rural South; the vast majority of them were landless farmers. ${ }^{20}$ For the post-Civil War South, the "negro problem" and

16. Also see David Hamilton, "Building the Associative State: The Department of Agriculture and American State Building," Agricultural History 64 (1990): 207-18.

17. Though many states in the nation adopted some of these racial governance structures during this time period, it was in the southern United States, particularly in the former states of the Confederacy, where these governing arrangements and institutions were adopted as a whole, and where they were largely unchallenged until the beginning of the Second Reconstruction in the late 1940s. But, see Desmond King and Stephen Tuck, who argue that the occurrence of lynchings outside of the South suggests that the Jim Crow order can be conflated with a national white supremacist order ("De-centering the South: America's Nationwide White Supremacist Order After Reconstruction," Past and Present 194 (2007): 219-57). On the end of Reconstruction, see Eric Foner, Reconstruction: American's Unfinished Revolution, 1863-1877 (New York: Harper \& Row, 1988). On the rise of Jim Crow, among many works see C. Vann Woodward, Origins of the New South, 1877-1913 (Baton Rouge: Louisiana State University Press, 1971); Edward L. Ayers, Promise of the New South: Life after Reconstruction (New York: Oxford University Press, 1993); Douglas A. Blackmon, Slavery by Another Name: The Re-Enslavement of Black People in America from the Civil War to World War II (New York; Doubleday, 2008).

18. See Desmond King and Rogers Smith, "Racial Orders in American Political Development," American Political Science Review 99 (2005): 75-92. For notions of "racialization" and racial formation, see Michael Omi and Harold Winant, Racial Formation in the United States, 53-76.

19. For analysis of black political power in the postReconstruction South, see J. Morgan Kousser, The Shaping of Southern Politics: Suffrage Restriction and the Establishment of the OneParty South, 1880-1910 (New Haven, CT: Yale University Press, 1974). agrarian unrest were uneasily linked together, especially in how southerners approached the development of the agricultural welfare state.

Within the Jim Crow order, two competing visions of an agricultural welfare state emerged that were each different from the agricultural welfare state envisioned by non-southern agrarians. First, compared to the rest of the United States, from 1880 to 1930, the South had a greater rural population and had a higher proportion of tenant farmers than elsewhere. ${ }^{21}$ In addition to these demographic differences, the southern white agricultural welfare state was distinctive from the non-southern welfare state in that, while many white farmers welcomed the benefits of the agricultural welfare state, white farmers and political leaders were suspicious of any USDA (and by extension federal government) policy initiatives that seemed to threaten the racialpolitical economy of the South. As these threats varied by state and local political economy, white southerners debated the terms of inclusion for black southerners in this welfare state. Some whites argued that African Americans did not possess the moral or intellectual fitness to participate in the structures of agrarian democracy. Others, however, argued that, while not capable of interaction on an equal level, blacks should be partially exposed to the agricultural welfare state in order to benefit the South as a whole. The collapse of populism and the rise of southern Progressivism, however, meant that any agricultural welfare state would be first and foremost for whites. $^{22}$ This goal was achieved as the price for the expansion of the agricultural welfare state was conceding local control over USDA programs to white southerners.

The southern black agricultural welfare state by contrast had a different goal: self-sufficiency and autonomy. Animated by slogans such as "own your own home - own your own farm," the black agricultural welfare state emerged to fill the void caused by the lack of public services for southern African Americans. Led by the Tuskegee Institute-"the headquarters for southern black welfare work"-and funded by Rockefeller's General Education Board (GEB), a small black agricultural welfare state-ranging from

20. For statistics on black population and land tenure, see Reynolds, Black Farmers in America, 4

21. Information on rural population of South from Joseph J. Spengler, "Population Problems in the South: Part I," Southern Economic Journal 3 (1937): 393-410. Size of farm tenant poplation calculated from "Series K 109-153, Farms by Race and Tenure of Operator, and Acreage and Value by Tenure of Operator: 18801969," U.S. Bureau of the Census, Historical Statistics of the United States from Colonial Times to 1970 (Washington, DC: Government Printing Office, 1975).

22. For "white" Progressivism of the South, see Jack Temple Kirby, Darkness at the Dawning: Race and Reform in the Progressive South (Philadelphia: Lippincott, 1972). 
USDA-funded county agents to foundation-funded teachers-emerged to address an economic and social crisis. ${ }^{23}$ Millions of African Americans emerged from slavery almost exclusively as landless agricultural laborers. In 1900, the first year in which reliable numbers are available, there were 740,000 black farmers: owners, tenants, and sharecroppers. By 1920 that number had increased to 923,000 . Despite this progress, from 1890 through 1930, most southern African American farmers (about 75 percent) were either tenants or sharecroppers rather than owners (see Table 1) ${ }^{24}$ Conditions for these farmers were difficult. ${ }^{25}$

The intersection of these regional visions of the agricultural welfare state with changes in nationallevel partisan alignments, congressional organization, and racial orders created a structure of two-tier agricultural citizenship for African Americans. One type of citizenship was formal inclusion (albeit separate and ultimately unequal), which rested on explicit statutory language such as "just and equitable" clauses, as well as through direct federal control of funding. ${ }^{26}$ The second type of citizenship was discretionary citizenship, in which the participation of African Americans in the agricultural welfare state was almost entirely dependent upon conditions within each local racial state and, more importantly, the relative strength or weakness of southern congressional Democrats at a given moment. ${ }^{27}$

The transition between different types of agricultural welfare citizenship for African Americans and

23. For discussion of a distinctive black welfare state, see Stephen Pimpare, "An African American Welfare State," New Political Science 29 (2007): 313-31, and also Susan L. Smith, "Welfare for Black Mothers and Children: Health and Home in the American South," Social Politics (1997): 49-64.

24. However, by 1969, the number of black farmers had decreased to 184,004; and to 18,451 by 1997 . See Reynolds, Black Farmers in America; and also Bureau of the Census, The Negro Farmer in the United States. Census of Agriculture, Fifteenth Census of the United States: 1930 (Washington D.C.: Government Printing Office, 1933).

25. See Charles S. Johnson, The Collapse of Cotton Tenancy (University of North Carolina Press, 1935) and Arthur F. Raper, Preface to Peasantry: A Tale of Two Black Belt Counties (University of North Carolina Press, 1936).

26. On the origins of the "just and equitable" clause, see Jean Preer, "Just and Equitable Division': Jim Crow and the 1890 LandGrant College Act," Prologue 22 (1990): 323-37. For discussion of types of inclusion in federal programs based on race or gender during the New Deal, in addition to Lieberman's Shifting the Color Line and Mettler's Dividing Citizens, see also Deborah Ward, The White Welfare State: The Racialization of US Welfare Policy (Ann Arbor: University of Michigan Press, 2005). Skocpol discusses the concept of differential inclusion in the chapter "African Americans in U.S. Social Policy," in Classifying by Race.

27. On local racial states, see David James, "The Transformation of the Southern Racial State: Class and Race Determinants of Local-State Structures," American Sociological Review 53 (1988): 191-208, and Regina Werum, "Sectionalism and Racial Politics: Federal Vocational Policies and Programs in the Predesegregation South," Social Science History 21, no. 3 (1997): 399-453.




the intersection of these types of citizenship with the broader transformation of the agricultural welfare state-from services to subsidies-are presented in Table 2.

Statutory language mandating formal inclusion of African Americans (albeit on a segregated basis) was a feature of the services-based agricultural welfare state from the very beginning. However, as the agricultural welfare state shifted increasingly from services to subsidies from the late 1910 s through the $1920 \mathrm{~s}$, inclusive language (as well as congressional debate) disappeared. It is not until the second New Deal (1936 to 1940) that attempts to formally include African Americans into the agricultural welfare state re-appear. In the next section I trace these transitions, in citizenship status and in policy choice, against a backdrop of changing congressional and partisan political orders.

\section{RACIAL INCLUSION AND THE SERVICES-BASED AGRICULTURAL WELFARE STATE}

The services-based agricultural welfare state began in a "big bang" of national expansion. The ThirtySeventh Congress (1861-1863) created the Department of Agriculture, passed the Homestead Act, and enacted the Morrill Land Grant Act. ${ }^{28}$ Early attempts to enact legislation for land-grant universities, as well a host of other "Hamiltonian-WhigRepublican measures for government promotion of socioeconomic development" had been blocked by southern congressmen wary of a larger federal government. ${ }^{29}$ President Pierce and President Buchanan had each vetoed earlier legislation, each arguing that the legislation was an unwarranted expansion of federal power in an area that had always been left to the states. ${ }^{30}$ The roadblock was removed with the start of the Civil War and the subsequent absence of southern Democrats from Congress.

28. Other legislation passed by the Thirty-Seventh Congress included authorization and funding for the Union-Pacific railroad; the abolition of slavery in Washington, D.C. and the territories; and the outlawing of polygamy. Lincoln and the Civil War Congresses were also responsible for the expansion of the army as well as the imposition of a range of taxes, including for the first time, an income tax. For discussion of Morrill Act see Coy F. Cross, Justin Smith Morrill Father of the Land-Grant Colleges (Lansing: Michigan State University Press, 1999); and Gordon C. Lee, "The Morrill Act and Education," British Journal of Educational Studies 12 (1963): 19-40.

29. See David P. Currie, "The Civil War Congress," University of Chicago Law Review 73 (2006): 1131-1226, 1143, and also Charles W. Calhoun, Conceiving a New Republic: The Republican Party and the Southern Question, 1869-1900 (Lawrence: University Press of Kansas, 2006).

30 . This veto was not unprecedented. In 1854, Pierce had vetoed a similar bill that would have funded state institutions for the insane. Buchanan also vetoed an early Homestead bill (see Lee, "The Morrill Act," 25).

\section{A. The Morrill Act (1862): Laying the Foundation}

The Morrill Act of 1862 established "land-grant institutions," in which states were given land scrip to be used for the establishment and/or expansion of a public university devoted to agriculture, the mechanical arts, and military science (see Table 2). To fund these institutions, each state or territory received 30,000 acres of public land for each senator and representative in Congress based on the 1860 census. ${ }^{31}$ Proceeds from the land were supposed to be used to support the institutions. ${ }^{32}$ In addition, an annual appropriation of $\$ 10,000$ was provided to each state, which increased by $\$ 1,000$ each year for the next ten years.

Contained within the legislation was an important provision: states that were "currently in rebellion" were not eligible for the grants. In addition, the act indirectly provided for states to establish separate schools for African Americans. Only four states would take up this provision immediately after the war: Kentucky (1866), Virginia (1872), South Carolina (1872), and Mississippi (1871). ${ }^{33}$ In each of these states, blacks exercised a degree of political power in the state legislature or via national Republican Party politics. Black citizenship in the agricultural welfare state was contingent, linked to, and supported by the fortunes of the national Republican Party. ${ }^{34}$

\section{B. Establishing Discretionary Citizenship: The Hatch-George Act}

Unlike the Morrill Act legislation, there was no debate about the status of African Americans in this bill. One reason for this absence could have been the increasingly hostile climate toward racial issues that was emerging across the nation in the aftermath of Reconstruction. ${ }^{35}$ While racial governance was not visible in

31. According to Lee, the grant amounted to about 11.3 million acres, "or about one-half the state of Indiana" (Lee, "Morrill Act," 26).

32. Ezra Cornell apparently was the most astute of the recipients, allegedly making nearly five times more from the land than the average state was able to (Lee, "Morrill Act," 28).

33. On the origins of black land-grant universities, in addition to Preer, "Just and Equitable Division,"” see also John W. Davis, "The Negro Land-Grant College," Journal of Negro Education 2 (1933): 312-28 and "The Participation of Negro Land Grant Colleges in Permanent Education Funds," Journal of Negro Education 7 (1938): 282-91. See also Thomas Adams Upchurch, Legislating Racism: The Billion Dollar Congress and the Birth of Jim Crow (Lexington: University Press of Kentucky, 2004).

34. For an analysis of black political power in the postReconstruction South, see J. Morgan Kousser, The Shaping of Southern Politics: Suffrage Restriction and the Establishment of the OneParty South, 1880-1910 (New Haven, CT: Yale University Press, 1974).

35. See Kousser, Shaping of Southern Politics, and also two works that discuss this era in some depth: Paul Frymer, Uneasy Alliances: Race and Party Competition in America (Princeton: Princeton University Press, 1999) and Richard M. Valelly, The Two Reconstructions: The Struggle for Black Enfranchisement (Chicago: University of Chicago Press, 2004). 
Table 2. Agricultural Welfare State Legislation: 1862-1950

\begin{tabular}{|c|c|c|c|}
\hline Services & Credit & $\begin{array}{l}\text { Price Support/ } \\
\text { Stabilization }\end{array}$ & Hybrid service/subsidy \\
\hline \multicolumn{4}{|l|}{ Morrill Act $(1862)^{*}$} \\
\hline \multicolumn{4}{|l|}{ Hatch-George Act (1887) } \\
\hline \multicolumn{4}{|l|}{ Morrill Act (1890 Land } \\
\hline \multicolumn{4}{|l|}{ Grant Act)* } \\
\hline \multicolumn{4}{|l|}{ Adams Act (1906) } \\
\hline \multicolumn{4}{|l|}{ Morrill-Nelson } \\
\hline \multicolumn{4}{|l|}{ Amendment (1907)* } \\
\hline \multicolumn{4}{|l|}{ Smith-Lever Act (1914) } \\
\hline & \multirow{3}{*}{\multicolumn{3}{|c|}{$\begin{array}{l}\text { Cotton Futures Act (1916) } \\
\text { Warehouse Act (1916) } \\
\text { Federal Farm Loan Act } \\
\quad(1916)\end{array}$}} \\
\hline & & & \\
\hline & & & \\
\hline \multicolumn{4}{|l|}{ Smith-Hughes Act (1917)* } \\
\hline & \multicolumn{3}{|l|}{$\begin{array}{l}\text { Capper-Volstead Act } \\
\text { (1922) }\end{array}$} \\
\hline & \multicolumn{3}{|l|}{$\begin{array}{l}\text { Agricultural Credit Act } \\
\text { (1923) }\end{array}$} \\
\hline \multicolumn{4}{|l|}{ Clarke-McNary Act (1924) } \\
\hline Purnell Act (1925) & \multicolumn{3}{|l|}{$\begin{array}{l}\text { McNary-Haugen bills } \\
\quad(1924-1928)\end{array}$} \\
\hline \multicolumn{4}{|c|}{ Capper-Ketchum Act (1928) } \\
\hline George-Reed Act (1929)* & \multicolumn{3}{|l|}{$\begin{array}{l}\text { Agricultural Marketing } \\
\text { Act (1929) }\end{array}$} \\
\hline \multicolumn{4}{|l|}{$\begin{array}{l}\text { Additional Federal } \\
\text { Cooperative Fund (1930) }\end{array}$} \\
\hline & Farm Credit Act (1933) & $\begin{array}{l}\text { Agricultural Adjustment } \\
\text { Act (1933) } \\
\text { Farm Credit Act (1933) } \\
\text { Emergency Farm } \\
\text { Mortgage Act (1933) }\end{array}$ & $\begin{array}{l}\text { Federal Emergency Relief } \\
\text { Act (1933) }\end{array}$ \\
\hline \multirow{2}{*}{\multicolumn{2}{|c|}{$\begin{array}{l}\text { George-Ellzey Act (1934) } \\
\text { Bankhead-Jones Act (1935)* }\end{array}$}} & Soil Conservation and & Resettlement \\
\hline & & $\begin{array}{l}\text { Domestic Allotment } \\
\text { Act (1936) }\end{array}$ & Administration Act (1935) \\
\hline \multicolumn{4}{|l|}{ George-Deen Act (1936) } \\
\hline & & & $\begin{array}{l}\text { Bankhead-Jones Farm } \\
\text { Tenant Act (1937) } \\
\text { Farm Security Administration } \\
\text { Act (1937) }\end{array}$ \\
\hline & & $\begin{array}{l}\text { Agricultural Adjustment } \\
\text { Act (1938) } \\
\text { Steagall Act (1942) }\end{array}$ & \\
\hline \multicolumn{4}{|l|}{$\begin{array}{l}\text { Bankhead-Flanagan } \\
\text { Act (1945) }\end{array}$} \\
\hline \multirow[t]{2}{*}{$\begin{array}{l}\text { George-Barden Act }(1946)^{*} \\
\text { Agricultural Marketing } \\
\text { Act }(1946)\end{array}$} & & & $\begin{array}{l}\text { Farmers Home } \\
\text { Administration Act (1946) }\end{array}$ \\
\hline & & $\begin{array}{l}\text { Agricultural Act (1948) } \\
\text { Agricultural Act (1949) }\end{array}$ & \\
\hline
\end{tabular}

*Equality clause included in legislation. 
the debate over the Hatch-George Act, the racial implications of the act would soon be apparent.

For reasons related to the struggle between the USDA and the states (primarily states that had multiple pre-existing experiment stations), a clause that would become critical to the shaping of the black agricultural welfare state was inserted into the final version of the bill: "That in any State or Territory in which two such colleges may have been or may be so established the appropriation made by this act shall be equally divided between such colleges, unless the Legislature of each State or Territory shall otherwise direct [emphasis added]. ${ }^{36}$ While not directly applicable to African Americans, this clause set an important precedent: funding for experiment stations would be controlled by state legislatures, though monies came from the federal government. Future programs of the agricultural welfare state that were attached to the experiment station legislation such as the Adams Act (1906), the Clark-McNary Act (1924), or the Purnell Act (1925) would reflect this discretionary control. Since no provision was made for separate funding for African American institutions at the beginning, federal and state legislators did not feel an obligation to provide any separate funding going forward from related programs to black institutions. ${ }^{37}$

\section{The Morrill Act of 1890}

The second Morrill Act, in 1890, expanded the landgrant university system to more states and territories. Better oversight and control mechanisms were instituted as a result of direct federal appropriations being granted. In addition to an assertion of greater federal oversight was an attempt to accommodate this new expansion of the agricultural welfare state to the waning of Republican Reconstruction and the rise of the Jim Crow order. Debate in Congress over the legislation addressed the issue of racial inequality in the South and the response of the federal government to those conditions. The remnants of the Reconstruction wing of the Republican Party were frank in their belief that white southerners would not deal fairly with their black population. Indeed, Senator John Ingalls (R-KS) remarked in debate,

While I am inclined to be entirely liberal to the Southern people and to recognize fully the difficulties under which they labor, while I don't impute to them any insincerity or any disingenuousness, I do not believe they like the

36. See R. Grant Seals, "The Formation of Agricultural and Rural Development of Policy with Emphasis on African Americans: II. The Hatch-George and Smith-Lever Acts," Agricultural History 65 (1991): 12-34; emphasis added, 20.

37. Another likely explanation for the exclusion of African Americans from the experiment station system was the fact that there very few black land-grant institutions that could house an experiment station, thus excluding or controlling them as a class was not an issue. colored people as well as they do the white people, and I think they must be put under bonds just the same as the Northern people must be put under bonds to do justice. ${ }^{38}$

Despite Ingalls's statement, the overall debate reflecting the increasing reluctance of Republicans to oversee southern affairs, and increasing hostility from southern Democrats at any perceived attempts by nonsoutherners in southern affairs. ${ }^{39}$

Morrill, sensing this divide, assured his fellow senators that the division of funds between white and black institutions would be left to each state's discretion. ${ }^{40}$ Morrill added an amendment:

no money shall be paid out under this act to any State or Territory for the support and maintenance of a college where a distinction of race or color is made in the admission of students, but the establishment and maintenance of such colleges separately for white and colored students shall be held to be in compliance with the provision of the act. ${ }^{41}$

In short, in order to persuade southern congressmen to support the bill, a separate yet equal provision was added. The debate over the Morrill bill would be the last discussion of formal inclusion of African Americans in the agricultural welfare state until 1914.

The response to the second Morrill Act by the southern states was rapid; within two years, almost all of them created parallel though not equal institutions for African Americans, bringing the total number of African American land-grant universities to seventeen. ${ }^{42}$ The law, however, did not spell out the specifics of what "just and equitable" meant; instead the legislation left the details to the Secretary of the Interior and the Commissioner of Education.

In 1893, with Cleveland's election, Hoke Smith became Secretary of the Interior; Smith would have some oversight authority over the federal distribution of the 1890 funds. While Smith was considered a Populist on account of his support for education, he increasingly had no love for African Americans. Indeed he ran for the position of governor of Georgia on a platform of such virulent white supremacy that it led to race riots in Atlanta. Together with Tom Watson, another former Populist, they would lead the campaign for the final and near total disenfranchisement of blacks, thus bringing Georgia firmly within the Jim Crow order. As senator, he would sponsor many of the signature

38. Preer, "'Just and Equitable Division,” 325.

39. Woodward, Origins of the New South, 456-81.

40. Preer, "Just and Equitable Division," 326.

41. Congressional Record, $51^{\text {st }}$ Congress, $1^{\text {st }}$ Sess., 21:6369.

42. In addition to the eleven states of the former Confederacy, the following states also established separate land-grant universities for blacks: Delaware, Kentucky, Maryland, Missouri, Oklahoma, and West Virginia. Both the Tuskegee Institute (Alabama) and the Hampton Institute (Virginia) were private institutions that also received land-grant funds. See Davis, "Negro Land Grant." 
pieces of legislation that would shape the agricultural welfare state. Yet as a southerner he was very clear that this state would not benefit blacks and whites equally. ${ }^{43}$

Although the Morrill Act set a statutory minimum of funding for black land grant institutions, the commitment of individual states to maintain a "just and equitable" sharing of funds between white and black institutions only lasted for about a decade (see Figure 1). From 1900 to 1932, the percentage of total federal and federal-state funds received by black land grant institutions steadily declined. Almost all black land-grant institutions received only the statutory minimum in funding during these decades.

These aggregate figures mask significant differences among southern states. For example, in 1900, Georgia allotted about 16 percent of the state's federal and federal-state funds to its black land grant institution; by 1920, the state decreased the allotment to about 4 percent of total funding. ${ }^{44}$ Georgia's African American population remained relatively steady at about 44 percent of the state's total population. North Carolina, which boasted of its peaceful race relations, allotted 23 percent of Federal and Federal-State funds to its black land grant institution in 1900. However, by 1920, the share of funds received by its black institution decreased to about 10 percent of the total federal and federal-state funding available. Again, as in the case of other states, there was no significant decrease in North Carolina's African American population.

\section{The Smith-Lever Act of 1914}

The Smith-Lever Act of 1914 marked the next great expansion, and in many ways the high point, of the services-based agricultural welfare state. The SmithLever Act provided federal support for the expansion and direction of educational services to farmers and their dependents. The southern Jim Crow order played a pivotal role in this expansion of the agricultural welfare state. A southern Democrat, Woodrow Wilson, held the presidency, while both the House and the Senate were under Democratic control, with southern Democrats making up 35 percent of the House and 43 percent of the Senate. In addition, southern Democrats were chairmen of powerful committees such as Rules, Banking and Currency, Judiciary, Interstate and Foreign Commerce, and, most

43. For discussion, see Werum, "Sectionalism and Racial Politics," 400-405; see also Philip A. Grant, "Senator Hoke Smith, Southern Congressmen, and Agricultural Education, 1914-1917," Agricultural History 60 (1986): 111-122, and Philip Grant, "Southern Congressmen and Agriculture, 1921-1932," Agricultural History 53 (1979): 338-51.

44. This figure and following figures in this paragraph are calculated by author from information presented in John Davis, "The Participation of Negro Land-Grant Colleges in Permanent Federal Education Funds," Journal of Negro Education 7 (1938): 289.

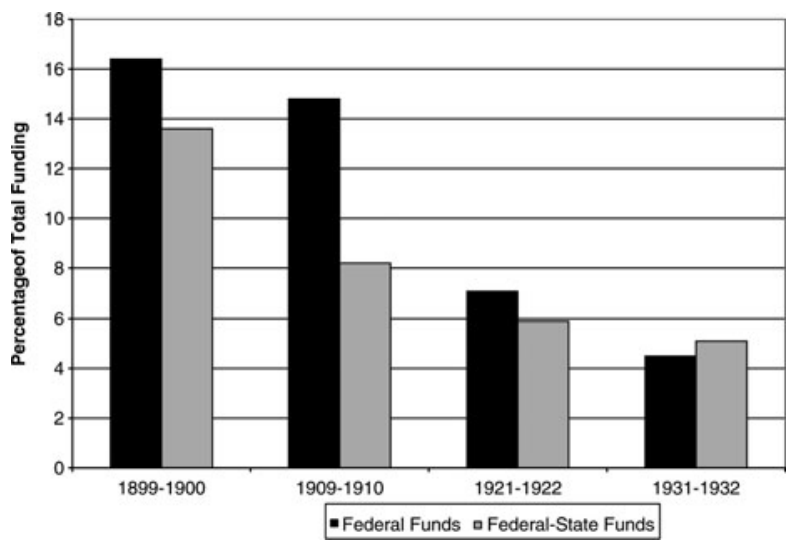

Fig. 1. Percentage of Federal and Federal-State Funds Received by African American Land-Grant Institutions, 1890-1932

Source: John Davis, "The Participation of Negro Land-Grant Colleges in Permanent Federal Education Funds," Journal of Negro Education 7 (1938): 289.

importantly, Agriculture. These positions were held by southern Democrats because of the seniority they accrued as a result of their safe seats. During the Democratic interregnum of 1912 to 1918, there existed a "southern imposition" on the shaping of the agricultural welfare state that had a decisive impact on African Americans' inclusion in that state. $^{45}$

In the House, hardly any debate occurred over the Smith-Lever Act; the bill was passed on a voice vote of 177 to $9 .{ }^{46}$ In the Senate, the issue of racial equality and southern manipulation of racial inequality was raised by Republicans. Senator Albert Cummins of Iowa objected that the bill's formula unduly favored the South. Eighty percent of the South's population lived in rural areas, and 35 percent of the country's rural population lived in the South. The open secret that much of this funding would be denied to African Americans only made the funding disparity more galling for midwesterners like Cummins. ${ }^{47}$ Senator Wesley Jones (R-WA) addressed the issue of racial equality head on. Like Senator Ingalls nearly twenty-five years earlier, Senator Jones raised doubts about the South's commitment to educational equity:

45. On southern congressional Democrats during the preNew Deal era, see, in addition to Werum, "Sectionalism and Racial Politics," Grant, "Senator Hoke Smith" and also Morton Sosna, "The South in the Saddle: Racial Politics during the Wilson Years," The Wisconsin Magazine of History 54 (1970): 30-49.

46. Two hours were given for debate, with no substantive criticism of the bill voiced. Seals, "Formation of Agricultural," 28-29.

47. Cummins also objected to the formula, which benefited southern states because of their higher proportion of rural population. See Congressional Record, 63rd Congress, 2nd Sess., $2425-29, \quad 2511-25, \quad 2650-60,2731-45, \quad 2929-48, \quad 3031-46$, $3115-30$. 
There has not been the opportunity for the colored boy and the colored girl that has come to the white boy and girl .... In other words, those who have charge of the colleges where the colored students go will have nothing to say as to how this money will be used or where it shall be used. ${ }^{48}$

In his speech to the chamber, Jones introduced statistics into the record that laid out the unequal status of the black land-grant institutions. As seen in Figure 1, by 1914, the percentage of federal and federal-state funds received by black land-universities had decreased. If land grant universities were to be the institutional home of an expanded agricultural welfare state, if no action was taken black institutions and black rural residents would remain in a disadvantaged position. To address this inequality, Jones proposed an amendment similar to that in the Morrill Act of 1890, which would apply the "just and equitable" standard to Smith-Lever funding. ${ }^{49}$

The decade-old NAACP ironically supported Jones's amendment, which called for the provision of a separate and equal standard. The NAACP found itself in this incongruous position of agitating for the inclusion of a separate and equal clause since the organization, as well as the administrators of the black land-grant institutions, believed that black institutions would not receive their fair share if funding was left up to the discretion of southern state legislatures. ${ }^{50}$ In short, the very claim of "separate and equal" had at least led to the issue getting a public hearing.

To this proposal, Senator Hoke Smith (D-GA), former Populist and now racial supremacist, answered,

I will tell the Senator frankly what we will do. We will put it in our white agricultural college. We would not appropriate a dollar in Georgia to undertake to do extension work from the negro agricultural and mechanical college. It would be a waste of money. ${ }^{51}$

This debate over racial equity in funding was the "first time that discrimination had been openly discussed in Congress" since the debate over the second Morrill Act; Smith's response, however, "reflected the supreme confidence of the South in getting its

48. Seals, "Formation of Agricultural," 22.

49. Preer, "'Just and Equitable,"” 334-36; also "Introduction of the Equity Amendment and Extensive Remarks on the Discriminatory Aspects of the Smith-Lever Bill," Congressional Record, $63^{\text {rd }}$ Congress, 2nd Sess., 2929-43.

50. Seals, "Formation of Agricultural," 30-31. For NAACP coverage of the issue, see "The Smith-Lever Bill and Other Work of the National Association for Advancement of Colored People," The Crisis 7 (March 1914): 247-48; "Congress. Smith-Lever Bill," The Crisis 7 (April 1914): 291-92; "The Smith-Lever Bill," The Crisis 8 (July 1914): 124.

51. Congressional Record, 63rd Congress, 2nd Sess., 2945. way." 52 Opposition to Jones's amendment was led by Smith and southern conservatives, while the supporters of equalization reflected midwestern and western Republican progressivism. ${ }^{53}$ In the end, southern Democrats won the debate and the vote. Jones's amendment lost, 32 to 23. The conference committee of six members included four southerners. There would be no guaranteed funding for black institutions. Any extension services would be allocated by the white institutions, although the actual service would be carried out by black male, and later female, agents. "Bare justice for the colored farmers," for which the NAACP had lobbied, was not granted. ${ }^{54}$

\section{Separate and Unequal under Smith-Lever}

The Smith-Lever Act of 1914 brought clear federal control over a system that was largely locally and/or privately funded, and whose administration rested under the aegis of state universities. The Act shifted the administrative oversight of extension agents away from universities to the USDA, which oversaw county agents that were paid for through federal, state, and local funds. These changes in administrative structure were accompanied by an increase in funding, which was now allocated on a formula based on rural population. Funding rose from about $\$ 480,000$ in 1914 to about $\$ 1.4$ million in 1915 . World War I and the need for increased food production provided a huge influx of funds into the extension program. By 1918, as a result of a series of supplemental funding acts, total federal funding increased to about $\$ 14$ million, bringing the federal government's share to 62 percent of the total program funding. Federal funding decreased after the war, contributing about 35 percent of the total funding until the agricultural legislation enacted during the New Deal, which increased the federal share to almost 60 percent. From 1914 through the 1920s, the extension movement grew to encompass about two thousand agents. By 1931, the number of agents had increased to about six thousand. After a brief drop during the Great Depression, New Deal legislation such as the Bankhead-Jones Act increased the number of extension agents by about one thousand. ${ }^{55}$

52. Seals "Formation of Agricultural," 22; Grant, "Senator Hoke," 116.

53. Southern conservative leaders included James K. Vardaman (D-MS) and Furnifold Simmons (D-NC). Republican Progressives included not only Jones (R-WA), but also Cummins (R-IA), Clapp (R-MN), Weeks (R-MA), Works (R-CA), Gronna (R-ND), McCumber (R-ND), Sterling (R-SD), and Sherman (R-IL).

54. Seals, "Formation of Agricultural," 31.

55. For a history of the county agent system, see M.C. Burritt, The County Agent and the Farm Bureau (New York: Harcourt, Brace, and Company, 1922); Gladys L. Baker, The County Agent (Chicago: University of Chicago Press, 1939); and Wayne Rasmussen, Taking the University to the People: Seventy-Five years of Cooperative Extension 
Under the Smith-Lever Act, compared to their proportion of rural population, black communities were absolutely far more underserved in terms of numbers of agents than white communities. ${ }^{56}$ In 1930 , white extension work received about $\$ 4.5$ million from the federal government, while black extension work received about $\$ 477,000$. In 1941 , of the 4,149 extension agents serving the South (the eleven states of the former Confederacy plus Kentucky, Oklahoma, Maryland, Missouri, Oklahoma, and West Virginia), 549, or approximately 13 percent of the agents, were African Americans. In areas where there were no black agents but a substantial black population, white agents had the choice, but rarely took it, to extend their services to African Americans.

As intended, the Smith-Lever Act was designed to be responsive to the needs of the Jim Crow order. As a result, the Act was implemented differently across the South with regard to serving each state's African American population (Table 3).

The funding/personnel gap ranged across time and across states. Compared to the other southern states, North Carolina and Virginia funded aboveaverage numbers of black county agents when the program was enacted (see Table 3). In states like Louisiana and South Carolina, only one or two agents were hired for the entire state. Nonetheless, in every state, the funding provided for extension services to blacks did not meet what should have been allotted to blacks if the "just and equitable" standard had been in place, and if the sprit of the standard had been embraced. Georgia was true to the words of Senator Hoke Smith, who had proclaimed that no funding would be given to black institutions. The state did not fund more than two black county agents from 1909 until 1914, when twelve agents were funded. The next year, Georgia only funded two agents; this in a state where 39 percent of all farmers were African Americans. In Alabama, home of Tuskegee and the intellectual leadership of the black agricultural welfare state, African American county agents made up only 19 percent of the state's

(Ames: Iowa State University Press, 1989). Also useful is Alfred True's A History of Agricultural Extension Work in the United States, 1785-1923, USDA Miscellaneous Publication No. 15 (Washington, DC: Government Printing Office, 1928) and his A History of Agricultural Experimentation and Research in the United States, 1607-1925 (Washington, DC: Government Printing Office, 1937). Data on county agents are from Burritt, County Agent, 192-209; Baker County Agent, 60; and True, History of Agricultural Extension, 197-202.

56. For a more detailed history of the black county agent system, see Earl W. Crosby, "Limited Success against Long Odds: The Black County Agent," Agricultural History 57 (1983): 277-88; Earl W. Crosby, "The Roots of Black Agricultural Extension Work," Historian 39 (2002): 228-47; Allan Jones, "The South's First Black Farm Agents," Agricultural History 50 (1976): 636-44; W.B. Mercier, Extension Work among Negroes, 1920, USDA Department Circular No. 190 (Washington, DC: Government Printing Office, 1921). total number of agents in 1937. However, based on the federal funding formula, black agents should have constituted approximately 53.7 of the state's agents. ${ }^{57}$

\section{E. The Culmination of the Services-Based State: Expansion Without Innovation}

Additional legislation steadily expanded the size of the services-based state. One last innovation in the services-based state was vocational education for agriculture, established by the Smith-Hughes Act (1917) and expanded by the George-Reed Act (1929), the George-Deen Act (1936), and the George-Barden Act (1946). The Clarke-McNary Act (1924) aided farmers in forestry management. The Purnell Act (1925) and the Capper-Ketchum Act (1928) expanded funding for experiment stations and the extension service.

Funding for the vocational education programs came partially through each state's land-grant universities. As a result, because of the early "just and equitable clause," some funding for education had to be shared between whites and blacks. In a 1932 report, researchers found that white institutions received almost four times the amount of funding of black institutions. Again, funding varied across states (see Table 4).

For example, Mississippi did not give any SmithHughes funding to black institutions, while Texas and Virginia gave slightly more funding to black institutions than to white ones. Behind these funding gaps was another important factor. From the beginning, the subsidy state was based on the idea of intergovernmental cooperation, with the federal, state, and local/ county governments sharing costs. At least with regard to African Americans, southern state and local governments almost exclusively funded agricultural welfare state services for blacks from federal funds (see Table 4).

In 1923, almost all states funded services for Africans Americans solely through federal monies. By 1937, this had changed, with the federal government funding only 77 percent of agricultural welfare state services to blacks. Again, these averages mask interstate variation. States like North Carolina and South Carolina significantly reduced their reliance on federal funds for programs for blacks. The lack of state involvement in funding services can be laid at

57. Figures for African American extension agents drawn from the following sources: Baker, County Agent, 191-26; W.B. Mercier, Extension Work among Negroes, 1920, USDA Department Circular No. 190 (Washington, DC: GPO, 1921); J.A. Evans, "Extension Work Among Negroes: Conducted by Negro Agents, 1923," USDA Department Circular No. 355 (Washington, DC: GPO, September 1925); and Doxey Wilkerson, Agricultural Extension Services Among Negroes in the South (Conference of Presidents of Negro Land Grant Colleges, 1942). Aggregate numbers for missing years from Monroe N. Work and Jesse Parkhurst Guzman, Negro Year Book, 1931-1932 (Tuskegee, AL: Negro Yearbook Publishing Co., 1931) and Gladys Baker, The County Agent (Chicago: University of Chicago Press, 1939). 
Table 3. African American Extension Agents in the South, 1910-1942

\begin{tabular}{lrrrrrrr}
\hline State & 1910 & 1914 & 1918 & 1922 & 1924 & 1936 & 1942 \\
\hline Alabama & 4 & 7 & 34 & 33 & 33 & 48 & 79 \\
Arkansas & 0 & 11 & 42 & 19 & 21 & 18 & 29 \\
Florida & 0 & 1 & 32 & 19 & 16 & 17 & 19 \\
Georgia & 1 & 12 & 37 & 23 & 29 & 46 & 50 \\
Kentucky & 0 & 5 & 0 & 3 & 5 & 5 & 7 \\
Louisiana & 0 & 1 & 17 & 14 & 15 & 19 & 20 \\
Maryland & 0 & 0 & 8 & 3 & 3 & 5 & 5 \\
Mississippi & 1 & 3 & 18 & 20 & 33 & 60 & 77 \\
North Carolina & 0 & 18 & 35 & 15 & 26 & 44 & 56 \\
Oklahoma & 1 & 2 & 0 & 0 & 13 & 17 & 20 \\
South Carolina & 0 & 0 & 10 & 14 & 14 & 33 & 37 \\
Tennessee & 0 & 0 & 11 & 9 & 9 & 19 & 21 \\
Texas & 0 & 0 & 19 & 22 & 36 & 77 & 87 \\
Virginia & 3 & 33 & 79 & 29 & 35 & 37 & 35 \\
West Virginia & 0 & 0 & 2 & 1 & 3 & 3 & 5 \\
Total & 10 & 93 & 344 & 224 & 291 & 498 & 547 \\
\hline
\end{tabular}

Note: The number of agents grew from 300 to 309 from 1925 to 1928, and to 325 in 1932.

Source: W.B. Mercier, Extension Work among Negroes, 1920, USDA Department Circular No. 190 (Washington, DC: GPO, 1921); J.A. Evans, "Extension Work Among Negroes: Conducted by Negro Agents, 1923," USDA Department Circular No. 355 (Washington, DC: GPO, September 1925); and Doxey Wilkerson, Agricultural Extension Services Among Negroes in the South (Conference of Presidents of Negro Land Grant Colleges, 1942). Aggregate numbers for missing years from Monroe N. Work and Jesse Parkhurst Guzman, Negro Year Book, 1931 - 1932 (Tuskegee, AL: Negro Yearbook Publishing Co., 1931) and Gladys Baker, The County Agent (Chicago: University of Chicago Press, 1939).

the door of state legislatures. Both in congressional testimony and in other research reports, the hostility of state legislatures toward spending state funds on African American services led many state extension directors to take funding solely from the federal funding stream. This tactic also allowed state directors to limit state legislative oversight of black extension work. $^{58}$ While this protected the black extension workers from the vagaries and hostility of southern state legislatures, this funding decision placed considerable powers into the hands of the white agricultural welfare state.

The last articulation of the services-based agricultural welfare state was the Bankhead-Jones Act (1935), which increased funding for the extension program but also provided subsidized loans and other programs for low-income farmers. As I discuss below, this Act tied welfare state services to a distinct class of farmers-the poor farmer in need of rehabilitation-and linked the services to financial subsidy programs. In addition, it signaled the re-emergence of racial equity language in agricultural welfare state legislation. This had a direct effect on funding, as seven states increased funding to African Americans (again on an unequal basis) soon after the legislation was enacted (see

58. For accounts of funding decision making, see "Further Development of Agricultural Extension Work: Hearings before the United States House Committee on Agriculture," 70th Congress, 1st Sess. (Jan. 10, 11, 16, 1928) (Washington, DC: GPO, 1928) and Baker, County Agent, 199.
Table 4). Despite these enactments, the funding for these programs was soon outstripped by the size of the subsidy programs enacted during the New Deal.

\section{THE FIRST TRANSFORMATION: FROM SERVICES TO COOPERATION}

While American farmers received record prices during World War I, the postwar era saw a decline in profits and in farm population. Farmers once again pushed for government relief, not only for services, but increasingly also for regulations and/or subsidies that would increase farmers' access to capital and credit. Many farmers also sought government policies that would act as a buffer between the individual producer and the market.

As the struggle over the future of agricultural policy continued through the 1920s, the future of agrarian democracy became increasingly uncertain. During the 1920s, the growing agitation on the part of some farm groups for more direct market intervention collided with a new turn in government philosophy. Led by figures such as Herbert Hoover, the 1920s would become known as the era of associationalism, where the federal government's intervention into economic matters would be mediated by private groups. ${ }^{59}$

59. For discussion of agriculture policy, associationalism, and the USDA in the 1920s, see David Hamilton, "Building the Associative State: The Department of Agriculture and American State 
Table 4. Federal/State Funding Supporting African American Participation in Selected Agricultural Welfare Programs in the South

\begin{tabular}{|c|c|c|c|c|c|}
\hline & $\begin{array}{c}\text { Federal Funds as } \% \\
\text { of all Agricultural } \\
\text { Welfare State } \\
\text { Spending on Blacks } \\
(1923)\end{array}$ & $\begin{array}{c}\text { Federal Funds as } \% \\
\text { of all Agricultural } \\
\text { Welfare State } \\
\text { Spending on Blacks } \\
\text { (1937) }\end{array}$ & $\begin{array}{l}\text { Black Share of } \\
\text { Smith-Hughes } \\
\text { Funds (1937) }\end{array}$ & $\begin{array}{c}\text { Black Share of } \\
\text { Bankhead-Jones } \\
\text { Funds (1937) }\end{array}$ & $\begin{array}{c}\text { "Equitable" } \\
\text { Proportion of } \\
\text { Funding that should } \\
\text { be allocated to } \\
\text { Blacks" }\end{array}$ \\
\hline Alabama & 99 & 100 & 26 & 0 & 36 \\
\hline Arkansas & 63 & 84 & 0 & 2 & 27 \\
\hline Florida & 90 & 85 & 25 & 0 & 31 \\
\hline Georgia & 84 & 95 & 21 & 0 & 38 \\
\hline Kentucky & 82 & 38 & 9 & 1 & 6 \\
\hline Louisiana & 92 & 72 & 47 & 0 & 41 \\
\hline Maryland & 95 & 43 & 0 & 5 & 18 \\
\hline Mississippi & 68 & 73 & 0 & 0 & 52 \\
\hline Missouri & 100 & 100 & 0 & 0 & 3 \\
\hline $\begin{array}{l}\text { North } \\
\text { Carolina }\end{array}$ & 86 & 53 & 21 & 2 & 29 \\
\hline Oklahoma & 100 & 100 & 1 & 0 & 7 \\
\hline $\begin{array}{l}\text { South } \\
\quad \text { Carolina }\end{array}$ & 100 & 34 & * & 0 & 48 \\
\hline Tennessee & 100 & 98 & 42 & 0 & 14 \\
\hline Texas & 85 & 72 & 59 & 1 & 15 \\
\hline Virginia & 85 & 87 & 58 & 0 & 27 \\
\hline $\begin{array}{l}\text { West } \\
\text { Virginia }\end{array}$ & 99 & 99 & 14 & 3 & 7 \\
\hline Average & 89 & 76 & 22 & 1 & 25 \\
\hline
\end{tabular}

Percentages calculated by author.

a Proportionality Measure based on average of each state's African American farm population, rural population, and total black population. * Missing data.

Sources:J.A. Evans, “Extension Work Among Negroes: Conducted by Negro Agents, 1923," USDA Department Circular No. 355 (Washington, DC: GPO, September 1925); Jesse Parkhurst Guzman, ed. Negro Year; A Review of Events Affecting Negro Life 1941-1946 (Tuskegee, AL: Department of Records and Research, 1947), 169; John W. Davis, "The Participation of Negro Land Grant Colleges in Permanent Education Funds," Journal of Negro Education 7 (1938): 282-91.

This shift in government philosophy was also accompanied by changes in partisan alignment and congressional organization. This new type of organization appeared within the backdrop of the business conservatism of the Republican resurgence of the 1920s. Not only did the Republican Party hold the presidency from 1922 to 1932, it also commanded clear majorities in Congress. The Republican insurgents and Progressives of the 1910s gradually disappeared. ${ }^{60}$ The Democratic Party was reduced to a regional party in national politics and was internally increasingly strained by divisions between its northern and

Building," Agricultural History 64 (1990): 207-18 and Elizabeth Hoffman and Gary D. Libecap, "Institutional Choice and the Development of U.S. Agricultural Policies in the 1920s," Journal of Economic History 51 (1991): 397-411. See also Carpenter, Forging of Bureaucratic Autonomy, 226-254; 290-325.

60. Charles W. Eagles, "Urban-Rural Conflict in the 1920s: A Historiographical Reassessment," Historian 49 (November 1986): 26-48; Otis L. GrahamJr., An Encore for Reform: The Old Progressives and the New Deal (New York: Oxford University Press, 1967). southern wings, culminating in the 1928 defeat of Governor Al Smith of New York. As an example of the dominance of the southern wing, from 1921 to 1923 southern Democrats made up 73 percent of all Democrats in the House, while twenty-two southerners dominated the party in the Senate. While Democrats were small in number, they exerted substantial institutional power as a result of the seniority they accrued via the Jim Crow order. The ranking Democrats on the Judiciary and the Banking and Currency committees were predominantly southerners. The credit bills of the 1920s originated from these two committees. In 1921, with the cooperation of the American Farm Bureau Federation, the Senate Farm Bloc was formally organized as a means to "bring together sufficient cooperative action in the Senate [in order] to enact legislative measures which would relieve agriculture." ${ }^{61}$

61. Christiana McFayden Campbell, The Farm Bureau and the New Deal (Urbana: University of Illinois Press, 1962), 34; and also, (30-43, 125-39). 


\section{A. Federal Farm Banks: The First Steps}

Small steps toward government intervention in the market took place beginning in the 1910s and on into the 1920s. First were the Cotton Futures Act of 1916, which established standards for cotton trading, and the Warehouse Act of 1916, which established regulation and licensing of warehouses for other agricultural products. ${ }^{62}$ These regulatory acts were followed by the Capper-Volstead Act of 1922, which promoted farmer cooperatives, and the Agricultural Credit Act of 1923, which created federal intermediate credit banks (see Table 2). ${ }^{63}$ None of these bills included statutory language about race. Thus, theoretically, all farmers would be equally served. Indeed, the leadership of the Federal Loan Board proclaimed the "solicitude" of the Board "for the extension of the privileges of the Farm Loan Act to colored farmers." "While the national board conceded that it had "neither the desire or the power to control" local associations, some members did feel that "the exclusion of a whole race is not in [their] opinion, within the ... implied power" of the local associations, as they are associated with a national organization. ${ }^{65}$

Despite these assurances, class and race did matter in the South. By and large, only landowners or those with a secure attachment to land could easily enter into the various cooperative marketing as well as relatively small-scale farm credit programs that were enacted during the 1920s. Outside of the South, tenantry did not pose an insurmountable hurdle in accessing these new sources of credit. Indeed, USDA policymakers reflected this nonsouthern bias, seeing tenantry as somewhat benign, a "natural step by which young men with limited capital become farmers."

62. The original Cotton Futures Act was passed in August 1914, and was found unconstitutional by the Supreme Court, which ruled that it was a revenue bill that had not originated in the House but rather the Senate. The 1916 act addressed this constitutional issue but was essentially the same as the 1914 act. Sanders argues that the Cotton Futures Act, the Warehouse Act, and the related Grain Standards Act of 1916 were all "clearly rooted in past and contemporary agrarian movements and reflected the goals of ... farmers to establish some control over the flow of credit," Sanders, Roots of Reform, 298-313.

63. See John E. Lee, Jr., "Southerners and Agriculture: Comment," Agricultural History 53 (1979): 372-76 and Grant, "Southern Congressmen and Agriculture."

64. Letter from Herbert Quick, Farm Loan Board member, to George Stevenson, President of the Federal Land Bank of Baltimore, November 7, 1917. Retrieved from www.farmcreditarchive. org, May 1, 2011.

65. Letter from George Stevenson, Federal Land Bank of Baltimore, to C.R. Caldwell, December 27, 1917. Retrieved from www. farmcreditarchive.org, May 1, 2011.

66. W. J. Spillman and E. A. Goldenweiser, "Farm Tenantry in the United States," Yearbook of the Department of Agriculture United States Department of Agriculture (Washington, DC: GPO, 1916), 321.
In the South, however, farm tenantry was fully enmeshed within the Jim Crow order as a manifestation of economic and racial inequality. ${ }^{67}$ While a significant percentage of whites were tenant farmers, the vast majority of black farmers were tenants as well as sharecroppers (see Table 1). As a result, many black farmers, particularly tenants, were largely unable to take advantage of these early credit or marketing programs, as credit was furnished through their landlords. As most black farmers were sharecroppers, their ability to access credit beyond what the landowner offered was limited.

Where landownership patterns were different, black county agents did try to assist in the creation of cooperative and credit associations. This was difficult, as most communities were unable to create their own credit facilities because there were no extra resources to put into a credit union or cooperative purchasing groups. For example, less than 2 percent of southern black farmers in 1929 participated in cooperative ventures, with an average sale of $\$ 674$ per association. ${ }^{68}$ The social-political economy of Jim Crow also weakened the effectiveness of these programs. Cooperative purchasing by blacks was resisted by many whites as it weakened local white merchants and raised the threat of increased black autonomy. Cooperative purchasing by whites and blacks together was in many instances impossible because of the color line.

Participation in Federal Farm Loan Banks was also shaped by the Jim Crow order. Eligibility for loans was based on membership in an association, and blacks were almost always denied membership (although few bothered to ask) ${ }^{69}$ In response to these denials, African American farmers petitioned to form their own associations. This strategy revealed a split within the Farm Loan Board organization. At the state level, officials stated that the practice was the best alternative available in instances when white associations refused to admit blacks. ${ }^{70}$ By contrast, officials

67. See Lee Alston and Joseph Ferrie, "Paternalism in Agricultural Labor Contracts in the U.S. South: Implications for the Growth of the Welfare State," American Economic Review 83 (1993): 852-76.

68. Numbers calculated from "Table 35: Sales and Purchases by Colored Farm Operators Through Farmers' Cooperative Organizations, and Value of all Products on Farms Reporting Cooperative Sales, by Southern Divisions and selected Northern States: 1929," in Charles E. Hall, Negroes in the United States, 1920-1932 (New York: Arno Press, reprinted 1969).

69. For a discussion of the credit situation for black farmers, see Crosby, "Limited Success," 284-87 and Roland B. Eustler, "Agricultural Credit and the Negro Farmer," Social Forces 8 (1930): 41921. The 1965 report issued by the U.S. Civil Rights Commission, Equal Opportunity in Farm Programs, discusses these inequalities in extensive detail.

70. Letters between Herbert Quick, Farm Loan Board member, and George Stevenson, Federal Land Bank of Baltimore, February 26, 1918 and March 12, 1918. Letter from Stevenson to C.R. Caldwell, December 27, 1917. Letter from Charles E. Lobdell, Federal Farm Loan Board, to John V. Van De Mark, 
at the regional and national levels were against the creation of "colored associations," as they increased the number of associations that the Board had to administer; and contradicted the Board's stated belief that all farmers were equal before the Board. To the national Farm Loan Board, the credit risk and character of an individual farmer counted more than a farmer's color. ${ }^{71}$

Since color did not officially matter, information about the number and amount of loans made to members of different races was not systematically collected. However, some fragmentary data are available. For example, the Farm Loan Board reported that in 1923, 46 colored farm loan associations, with a total membership of 1,672 , had been created. ${ }^{72}$ Despite these attempts at self-organization, the black press charged in 1929 that black farmers were "not able to get the benefits" of the Act, and that many had "become discouraged."73 Thus the first steps toward the subsidy-based agricultural welfare state bypassed many black farmers. This exclusion was not mandated by statute; rather the exclusion reflected the intertwining of race and class within the Jim Crow order.

\section{B. The McNary-Haugen Struggle: The Beginnings of the Subsidy State}

Attempts to enact more direct types of financial intervention in the agricultural market would prove to be controversial, as seen in the intermittent and unsuccessful attempts from 1924 to 1927 to enact the McNary-Haugen bills, which called for a bundle of pricing, loan, and tariff mechanisms that would provide subsidies for the farm sector (see Table 2). ${ }^{74}$ Two early bills failed to pass in Congress. However, the gradual decline in cotton prices in the late 1920 s pushed many southern members of Congress to take an active interest in market-based agricultural programs. Thus, in the 1927 and 1928 bills,

Federal Land Bank of Houston, October 22, 1921. Letters retrieved from www.farmcreditarchive.org, May 1, 2011.

71. Letter from George Stevenson, Federal Land Bank of Baltimore, to C.R. Caldwell, December 27, 1917. Retrieved from www. farmcreditarchive.org, May 1, 2011.

72. Evans, Extension Work Among Negroes, 14.

73. "Farm Relief Legislation Shuts Out Race Farmers," Pittsburgh Courier (June 22, 1929), p. A8.

74. The McNary-Haugen bills called for putting aside surplus production and then dumping it on foreign markets. It was believed that this would raise domestic prices. For discussion of the McNary-Haugen bills, see John D. Black, "The McNaryHaugen," The American Economic Review 18 (1928): 406-27; Kimberly K. Porter, "Embracing the Pluralist Perspective: The Iowa Farm Bureau Federation and the McNary-Haugen Movement," Agricultural History 74 (2000): 381-92; and Gilbert C. Fite, George N. Peek and the Fight for Farm Parity (Norman: University of Oklahoma Press, 1954). Not all agrarian activists were in favor of McNary-Haugenism-Rexford Tugwell offered a sharp critique in "Farm Relief and a Permanent Agriculture," Annals of the American Academy of Political and Social Science 142, Farm Relief (March 1929): 271-282. which passed in the House (213-178 and 204121), southerners switched to supporting the bill alongside midwesterners, while representatives from the East remained largely opposed. Lobbying by the Farm Bureau, coupled with the self-interest of southerners and their emerging sense of acting as a regional bloc helped to keep a more active role for direct government intervention on the congressional agenda. ${ }^{75}$ Coolidge's vetoes ultimately blocked these bills.

The election of Hoover in 1928 produced additional movement toward direct government intervention. With Hoover's support, the Agricultural Marketing Act, which incorporated some of the provisions contained in the earlier bills, was passed by Congress in 1929. ${ }^{76}$ The Agricultural Marketing Act of 1929 created the Federal Farm Loan Board, strengthened farmer cooperatives, and introduced price stabilization efforts with a $\$ 500$ million revolving fund. Again, black farmers would complain that they were largely excluded from these new credit and marketing programs. ${ }^{77}$

\section{THE NEW DEAL AND THE TRANSFORMATION OF THE AGRICULTURAL WELFARE STATE}

The Great Depression hit American agriculture hard and southern agriculture the hardest. Cotton prices fell from nearly $\$ 17$ per pound in 1927 to $\$ 5.60$ per pound between 1929 and 1931. This economic collapse was accompanied by the beginning of a political realignment. Franklin Roosevelt was elected president in 1932 with the Democratic Party capturing overwhelming majorities in the House (313-117) and in the Senate (59-36). Democrats held the presidency from 1932 until the 1953 election of Eisenhower, when Democrats briefly lost the House and the Senate in the Eighty-Third Congress. Until Eisenhower's election, the Republican Party was reduced to the minority party status that Democrats had occupied a decade earlier. Because of their party's dominance and as a result of their accrued seniority, southern Democrats became one of the obstacles around which Roosevelt would have to craft agricultural policy.

The Depression energized what had been a slow and hesitant shift toward direct government

75. See Schapsmeier and Schapsmeier, who argue that from the 1920s through the New Deal there existed a serious split within the southern congressional delegation between the "Jeffersonian purists and radically oriented neo-Populists." Edward L. Schapsmeier and Frederick H. Schapsmeier, "Farm Policy from FDR to Eisenhower: Southern Democrats and the Politics of Agriculture," Agricultural History 53 (1979): 352-71, 355.

76 . The bill passed in the House on a 366 to 35 vote; and in the Senate on an 87 to 4 vote. In each case, southerners overwhelming supported the measure.

77. See "Farm Relief Legislation Shuts Out Race Farmers." 
intervention on behalf of the farmer. The enactment of the Agricultural Adjustment Act (AAA) of 1933, which introduced production controls in order to stabilize commodity prices, and the Farm Credit Act of 1933, which extended short-term and low-interest loans for farmers, were the first of a flurry of legislation and executive orders aimed at rescuing the agricultural sector. ${ }^{78}$ When the Supreme Court declared the AAA unconstitutional, it was swiftly replaced by the Soil Conservation and Domestic Allotment Act of 1936. Later, a new Agricultural Adjustment Act was enacted in 1938, which permanently established the concept of crop subsidies (see Table 2).

\section{A. Income Protection and the Modern Subsidy State}

Precedent and southern political power played a pivotal role in the shaping of New Deal agricultural legislation. In the case of the AAA of 1933 and the Soil Conservation Act, the existence of the organizational infrastructure of the county agent system shaped the decision to administer these programs through county-level committees assisted by county extension agents in order to quickly affect farmers' production decisions. In the South, where county agents shared a much stronger connection to local elites and not to the land-grant institutions, this meant that local elites played a much larger role in determining the program's beneficiaries. The formal involvement of the county agent was brief. By the time the Agricultural Adjustment Act of 1938 was enacted, a separate county committee system was created, joined by the Soil Conservation program. Both of these program's administrative structures bypassed the extension service. The extension was upset by this decision, seeing it as decision to delink it from a significant part of the USDA's expanded mandate. For African American farmers, there would be a long-tem negative effect of this administrative decision as well. The lack of extension involvement meant that black agricultural agents had no institutional means to influence the decisions made by these county committees.

Theoretically, the ability of African Americans to affect this new agricultural policy existed. New Dealers did take pains to emphasize that African Americans would have the right to vote in AAA elections. The record of black participation in these elections is mixed. In some communities participation was high, although some critics have argued that this participation was coerced by landlords and

78. For reasons of space, not all New Deal agricultural legislation can be discussed. Some important early New Deal legislation and/or policies enacted included the Emergency Farm Mortgage Act 1933; the creation of the Farm Credit Administration (Executive Order No. 6340, October 16, 1933); Frazier-Lemke Farm Bankruptcy Act (1934); the Bankhead Cotton Control Act (1934); and the Kerr-Smith Tobacco Control Act (1934). other white elites. Other research suggested that initially some black farmers participated warily but openly in the AAA elections. ${ }^{79}$ Despite the initial encouraging signs, the results of future AAA elections did not point to an increase in the empowerment of African American farmers. For example, a 1965 Civil Rights Commission study found that, as of 1962, no African American had ever been appointed to a state committee for the Soil Conservation Service and that no black person had ever been elected to a county committee. The study also found that the average black farmer was usually allotted less than a fifth of the cotton acreage allotted to white farmer. ${ }^{80}$

The agricultural stabilization programs had another effect on black farmers, especially tenant farmers and sharecroppers. Lack of oversight and enforcement meant that price support payments were kept by landowners, while incentives to decrease production encouraged landowners to evict tenants and especially sharecroppers. In hindsight, the results were predictable: tenants and sharecroppers were pushed off the land. The number of tenants and sharecroppers of both races fell by an average of 23 percent. The number of black tenants and croppers in the South fell by 200,000 from 1930 to $1940 .{ }^{81}$ Yet the shift in the South was not wholly a result of the southern elite growers: as established during the 1920s, the agricultural subsidy policy favored those with clear property rights, a preference which reflected the power of midwestern and western farmers who operated under differing farming models.

\section{B. From Farmers to "in Need of Rehabilitation": The End of Agrarian Equality}

As a result of the unintended consequences of early New Deal legislation, by 1936, New Deal liberals had recognized a new crisis in southern agriculture: the poor farmer, and especially the poor tenant farmer

79. See Robert E. Martin, "Negro-White Participation in the A.A.A. Cotton and Tobacco Referenda in North and South Carolina: A Study in Differential Voting and Attitudes in Selected Areas" (Ph.D. dissertation, University of Chicago, 1947) and also Sidney Baldwin, Poverty and Politics: The Rise and Decline of the Farm Security Administration (Chapel Hill: University of North Carolina Press, 1968). Jess Gilbert and Carolyn Howe argue that the expansion of the Farm Bureau during the 1920s undermined the ability of more radical organizations like the Southern Farmer's Tenant Union, the Non-Partisan League, and the Farmer-Labor Party to offer an alternative broad-based and cross-sectional opposition to the AAA. They also argue that different agricultural sectors influenced AAA policy ("Beyond 'State vs. Society': Theories of the State and New Deal Agricultural Policies," American Sociological Review 56 (1991): 204-20).

80. See U.S. Civil Rights Commission, Equal Opportunity, 89-95.

81. In addition to Reynolds, Black Farmers in America, see also Pete Daniel, Breaking the Land: The Transformation of Cotton, Tobacco, and Rice Cultures since 1880 (Urbana: University of Illinois Press, 1985). 
and sharecropper. ${ }^{82}$ Advocates both within government and outside pushed for legislation that would soften the blow of the AAA and other early agricultural programs. The new programs would come under the umbrella of rural rehabilitation for farmers considered unable to join the commercial farmers being served by the subsidy programs.

A number of programs were created to address the need for rural rehabilitation (see Table 2). The Federal Emergency Relief Act of 1933 was joined by the establishment of the Resettlement Administration in 1935, which in turn was joined by the BankheadJones Tenant Farm Act of 1937. The Farm Security Administration (FSA) Act of 1937 consolidated a number of these programs, and by 1946 the Farmers Home Administration assumed control of many of the surviving programs.

This new legislation in some ways ended the democratic agricultural welfare state, a state in which services were provided to rural residents as of right rather than based on economic need. Those who could not compete under modern conditions would essentially receive welfare. This transformation was complicated by the political setting in which it took place- Roosevelt's "second New Deal." While Democrats still commanded majorities in both chambers, the immediate sense of crisis had lessened and new fissures were appearing. The building blocks of the New Deal coalition were just being put together, with southern Democrats finding themselves in an uneasy coalition with union members, northern ethnics, and black migrants from the South.

A glimpse of these possible fissures in this nascent New Deal coalition can be seen in the reappearance of equality clauses and the notion of equality and formal inclusion in debates over agricultural welfare state legislation. Contributing to the rise of the New Deal Democratic coalition were northern African Americans voters, who emerged as significant political coalition actors for the first time since the end of the first Reconstruction. ${ }^{83}$ One example of the return of the equality clause and the rise of African American political strength was the debate over the GeorgeEllzey Act in 1934, which would have increased funding for vocational education. Representative Oscar De Priest (R-IL), the first African American elected to Congress since the ascension of the Jim Crow order, offered an amendment that funds would be "equally distributed by race in all states with de

82. For a contemporary account of the crisis in southern agriculture, see Johnson, The Collapse of Cotton Tenancy; Raper, Preface to Peasantry; and also Thomas J. Woofter, Landlord and Tenant on the Cotton Plantation (Washington, DC: Works Progress Administration, 1936).

83. On the rise of northern African American voters and the New Deal coalition, see Frymer, Uneasy Alliances, and Valleley, The Two Reconstructions. jure segregation." ${ }^{84}$ The amendment failed, but as Werum notes in her analysis, this was the first time since the debate over the Smith-Lever Act that an equality clause was debated by Congress. Although De Priest was not a formal member of the New Deal coalition, he did represent the fact that urban blacks were beginning to play a larger role in Democratic Party politics.

\section{The Farm Security Administration (FSA) and the Constraints of the Jim Crow Order}

Although charged with addressing the needs of the displaced and threatened agricultural worker, administrators of the Resettlement Act and later the FSA became increasingly cautious about pushing the boundaries of the Jim Crow order. Thus, the emphasis shifted from simply relief to selection of clients based on their status as "good risks." This posture tended to harm black farmers, since as a group they were economically more vulnerable than white farmers. For example, in 1945, the average black farm was about 60 acres and the average white farm was about 156 acres. Despite this economic inequality, the FSA allotted loans based on population percentage. This meant, as Richard Sternsher shows in his analysis The Negro's Share that "more than one out of every five needy white farm families was assisted ... [but] only one out of nine of the comparable colored families was given such assistance." 85 There was another critical limit on what the BankheadJones program as well as the FSA could do for southern African Americans: applications for loans for farms, houses, seeds, equipment, and other types of aid still needed to be approved by the allwhite county committee.

Nevertheless, despite these efforts by the FSA to hew to the boundaries of the Jim Crow order, it as well as other New Deal programs became the subject of southern opposition as southern Democrats increasingly turned against those parts of the New Deal that they felt threatened the Jim Crow order. $^{86}$ Indeed, the southern members of Congress

84. For discussion of this incident, see Werum, "Sectionalism and Racial Politics," 420 and Congressional Record, $73^{\text {rd }}$ Congress, $2^{\text {nd }}$ Sess.,7:7477, for the objections raised by southern congressmen.

85. For figure for average acreage, see Jesse Parkhurst Guzman, Lewis Jones and Woodrow Hall, eds. Negro Yearbook: A Review of Events Affecting Negro Life, 1952 (New York: William H. Wise \& Co, Inc), 105. For a discussion of FSA numbers, see Richard Sterner, The Negro's Share: A Study of Income, Consumption, Housing and Public Assistance (New York: Harper \& Brothers, 1943), 298, and 300 for quote.

86. For discussion of southern congressmen's counter-reaction to the New Deal, see Ira Katznelson, Kim Geiger, and Daniel Kryder, "Limiting Liberalism: The Southern Veto in Congress, 1933-1950," Political Science Quarterly 108 (1993): 283-306 and Sean Farhang and Ira Katznelson, "The Southern Imposition: Congress and Labor in the New Deal and Fair Deal," Studies in American Political Development 19 (2005): 1-30. 
saw the FSA as essentially a welfare program. Not only did they consistently underfund the program, but as soon as they were able, they cut off funding and essentially killed the FSA, which McConnell dubbed the "poor man's Department of Agriculture." 87 Rather than being perceived as agricultural citizens, lower class farmers, both black and white, became recipients of rural relief efforts governed not by the sympathetic USDA but by what conservatives dubbed a "government bureaucracy gone mad." 88

\section{The Modern Agricultural Welfare State and Two-Tier Citizenship}

By 1940, the agricultural welfare state had embarked in a significant new direction from the tentative steps taken in the 1920s. For example, in 1937, direct government payments to farmers totaled $\$ 336$ million, dwarfing the $\$ 41$ million in federal funding to the services-based welfare state. ${ }^{89}$ While the logic of modern capitalist agribusiness may have led to this transformation of the agricultural welfare state, it was not inevitable. As Sheingate notes in his work, agricultural and rural interest groups in other countries met with varied success in their ability to protect the interests of small farmers. ${ }^{90}$ In the United States, however, this was not the case. The agricultural welfare state based on services to all farmers and rural residents envisioned by the radical farmers of the late nineteenth century had stalled, while a market-based agricultural welfare state that primarily aided larger farm operators and especially large landowners, was rapidly gaining strength.

This market-based economic logic was accompanied by a long-standing racial logic. The post-New Deal extension program reflected the long-standing two-tier system that existed in the southern agricultural welfare state. White extension agents aided mostly white farmer-owners in their transition to modern agriculture, providing access to technical information and aiding them in obtaining credit for financing the machinery and acreage necessary to compete in the new agricultural market. Black extension agents were not given this power; indeed given their separation from the county committee system that administered the subsidy system, they did not have the means to help their clients. Instead African American agents

87. McConnell, Decline, 89. For discussion of the demise of the FSA, see Baldwin, Poverty and Politics and also Patricia Sullivan, Days of Hope: Race and Democracy in the New Deal Era (Chapel Hill: University of North Carolina Press, 1996), 124-29.

88. Gilbert and Howe, "Beyond State vs. Society," quoting a contemporary and conservative critique of the FSA, 216.

89. For spending on subsidies, see U.S. Bureau of the Census, "Series K 326-329, Direct Government Payments to Farmers, by Program: 1933 to 1970," Historical Statistics of the United States from Colonial Times to 1970 (Washington, DC: GPO, 1975); for spending on land grants, see Rasmussen, Taking the University, 252-53. $28-37$. were directed to help black farmers achieve selfsufficiency. This was an objective of the black welfare state from its inception, but had achieved little success. In the postwar economy, it was an increasingly anachronistic goal. ${ }^{91}$ Despite the continued efforts of black county agents, African American farmers were pulled off the land by more lucrative opportunities in cities and pushed off by the increasing inability to access the few remaining benefits of agricultural citizenship. With little to keep them in the country, the number of black farm operators declined. In 1945, the number of nonwhite farm operators in the South was approximately 475,000; by 1959 the number had decreased to about $138,000 .^{92}$

\section{CONCLUSION}

The development of the agricultural welfare state took place across a backdrop of significant political, economic, and social changes that occurred from the Civil War to the New Deal. As initially conceived, the goal of the agricultural welfare state was to provide farmers-primarily men, but later wives and children-a means to confront and adapt to not only an increasingly urban and industrial nation, but also an agricultural economy undergoing a transformation from subsistence agriculture to commercial farming aimed increasingly at national and international markets. Through the apparatus of state land-grant universities, a broad array of services were provided to the farmer. However, as this article has shown, the intersection of multiple political orders shaped the evolution of the agricultural welfare state in a variety of ways.

First, the existence of the Jim Crow racial order, as reflected in the local governing coalitions in the South and, at the national level, a long-standing, cohesive, and durable representation of southern racial interests within Congress, pushed the development of this state in a distinctive direction. As the discussion of the early subsidy-based state shows, the need to delegate control over national programs to local actors in order to gain southern congressional support led to the granting of broad discretionary power to state and local political and bureaucratic

91. For discussion of post-New Deal era, see Jeannie M. Whayne, "Black Farmers and the Agricultural Cooperative Extension Service: The Alabama Experience, 1945-1965," Agricultural History 72 (1998): 523-51; Jeannie M. Whayne, "The Segregated Farm Program in Pointsett County, Arkansas," Mississippi Quarterly 45 (1992): 421-38; Debra A. Reid, Reaping a Greater Harvest: African Americans, the Extension Service, and Rural Reform in Jim Crow Texas (College Station: Texas A\&M University Press, 2007); Joel Schor, "The Black Presence in the U.S. Cooperative Extension Service Since 1945: An American Quest for Service and Equity," Agricultural History 60 (1986): 137-53. and Pete Daniel, "African American Farmers and Civil Rights," Journal of Southern History 73 (2007): 3-38.

92. Reynolds, Black Farmers in America, 24. 
actors. Once this discretion was established, and absent a political coalition to overturn this discretion, any inequality established at the beginning became cumulative in scope.

Although the potential for the subsidy state to be broadly inclusionary was apparent, and made real for many farmers, for African Americans, at least, inclusion was on a limited and decidedly unequal basis. In some ways, this is not surprising, as racial inequality has long been a feature of American governance, especially during the period covered in this article. The very obviousness of racial inequality and its linkage to a federal system of governance has by now been understood to shape the development of American social welfare programs in predictable ways. The desire on the part of racial orders based on inequality to maintain their political and ideological commitments as well as any political or economic institutions that surround and/or support these commitments can lead in some cases to a distinctive type of state formation. Under this type of political ordering, national control over policy implementation is ceded to the state and local level. While this outcome has been widely documented in research on the development of the American social welfare state, as this article shows, the same approach has not been taken with understanding the emergence and transformation of the agricultural welfare state.

By reconceptualizing the development of the agricultural welfare state through an alternative analytical lens, a different understanding of its development can be seen. Rather than seeing the agricultural welfare state has emerging almost hand-in-hand with interest groups like the American Farm Bureau Federation, an alternative story of politics can be developed that is rooted in partisan conflict, congressional organization, and the institutional structure of the American federal system. Narrowly focused interest groups became increasingly influential in shaping agricultural policy as the agricultural welfare state gradually shifted away from a structure designedalbeit never perfectly-to support broad egalitarian goals, to a structure in which the goals of the farmer had been steadily narrowed to focus on income protection.

The 1920s stand as an important transitional moment. The prior decade had shown the emergence of a strong and active coalition of southern congressmen who actively protected the interests of the southern political economy. Standing against this southern bloc were the last remnants of Republican racial egalitarians. When Republicans regained control of the national government in the 1920s, these Republican egalitarians were largely gone, as was political support for insisting on explicit racial inclusion in the agricultural welfare state. Gone as well was a sense of the agricultural welfare state as being a source of support for all farmers-rather it was reimagined as a means of supporting individual farmers based on character, and more importantly, on credit-worthiness. To the extent that farmers worked together, it was under the banner of an associationalism compatible with modern capitalism, not agrarian radicalism.

The focus of early New Deal agricultural policy on income and price support cemented the eclipse of the services-based state and served to entrench subsidy support programs. Only belatedly did the social and economic costs of these new policies on African Americans and poor farmers in general become apparent. Perhaps as an acknowledgment of the growing role of northern African American voters, policymakers did attempt to address the unequal aspects of early New Deal agricultural policy. However, the organizational, political, and institutional arrangements that had been built up around two-tier agricultural citizenship were never really disturbed. Instead, through programs like the FSA, policymakers made awkward and inadequate efforts to bring farmers back into the first tier of citizenship through individual rehabilitation rather than through a program that could encompass all farmers.

The results from this analysis should strengthen our understanding of how the American welfare state has been shaped. In particular, the role of federalism and the durability of state and local government units was, and perhaps continues to be, an important factor an American welfare state development. However, American federalism, at least in this analysis, cannot be disentangled from issues of race, and especially the existence of racial orders. While the racial discrimination engaged in by the USDA in the post-civil rights era may have been the result of individual actions, this analysis has shown that racial governance and racial orders are deeply embedded in the American state building process. 